\title{
Bukti Empiris Penerapan Prinsip-Prinsip Good Cooperative Governance pada Kinerja Koperasi di Sukabumi
}

\author{
Tri Endar Susianto ${ }^{1}$, Suyatno ${ }^{2}$ \\ ${ }^{1}$ Universitas Pancasila, Jl. Srengseng Sawah, Jagakarsa, Jakarta Selatan 12640 \\ ${ }^{2}$ Sekolah Tinggi Ilmu Ekonomi IPWI Jakarta, Jl. Letda Natsir No.7 Nagrak, Gn. Putri Cibubur, Bogor
}

\section{N F O A R T I K E L}

\author{
JEL Classification: \\ D22 \\ H30
}

Keywords:

Transparency,

accountability,

responsibility,

fairness, and

performance.

\section{$A B S T R A C T$}

This study aims to identify and analyze that information transparency, accountability, responsibility, fairness affect the performance of the cooperative. The method of sample selection in this study was purposive sampling resulting in 124 samples of cooperative management. The data required in this study was obtained from the department of cooperatives in Sukabumi. Data analysis method used is multiple linear regression. The results showed that accountability, transparency, accountability, and fairness significant effect on performance. The results of this study are expected to contribute to the implementation of good governance in cooperatives in Indonesia

\begin{abstract}
A B S T R A K
Penelitian ini bertujuan untuk mengetahui dan menganalisis bahwa keterbukaan informasi, akuntabilitas, pertanggungjawaban, fairness berpengaruh terhadap kinerja koperasi. Metode pemilihan sampel dalam penelitian ini adalah purposive sampling sehingga menghasilkan 124 sampel pengurus koperasi. Data yang diperlukan dalam penelitian ini diperoleh dari dinas koperasi kota Sukabumi. Metode analisis data yang digunakan adalah regresi linier berganda. Hasil penelitian menunjukkan bahwa akuntabilitas, transparansi, pertanggungjawaban, dan fairness berpengaruh signifikan terhadap kinerja. Hasil penelitian ini diharapkan dapat memberikan kontribusi dalam penerapan tata kelola yang baik pada koperasi di Indonesia.
\end{abstract}

\section{Pendahuluan}

Koperasi adalah suatu badan usahayang didirikan oleh sekolompok orang yang mempunyai kepentingan yang sama dengan tujuan meningkatkan kesejahteraan anggotanya. Koperasi merupakan gerakan ekonomi rakyat yang berdasarkan atas asas kekeluargaan. Pada Undang-Undang Republik Indonesia No 25 tahun 1992 yang menegaskan bahwa :Koperasi adalah badan usaha yang beranggotakan orangseorang atau badan hukum Koperasi dengan melandaskan kegiatannya berdasarkan prinsip Koperasi sekaligus sebagai gerakan ekonomi rakyat yang berdasar atas asas kekeluargaan.

Sebanyak 164 unit Koperasi di Kota Sukabumi, Jawa Barat kondisinya saat ini tidak sehat. Faktor penyebabnya antara lain kurangnya permodalan dan lemahnya pengelolaan manajemen Koperasi. Koperasi-

*Email Korespondensi: ${ }^{1}$ celo_men@yahoo.com, ${ }^{2}$ suyanto@cbn.net.id 
Koperasi di Kota Sukabumi masih banyak yang kurang transparan dalam pelaporan keuangan terbukti hanya beberapa Koperasi yang melaporkan laporan keuangan kepada Dinas Koperasi Kota Sukabumi. Begitu pula akuntabilitas dan pertanggungjawaban pada Koperasi masih jauh dari yang diharapkan, banyak Koperasi yang masih terkesan lari dari tanggung jawab dengan tidak melaporkan selisih hasil usaha pada Dinas Koperasi dan juga tidak jelasnya laporan keuangan yang dipublikasikan kepada anggotanya. Dengan demikian Koperasi tersebut secara otomatis tidak menjalankan fungsinya yang tertuang dalam Undang-UndangNomor 25 tentang pertanggungjawaban.

Profesionalisme karyawan juga sangat diperlukan dalam menunjang kemajuan dari koperasi, banyak di antara koperasi di Kota Sukabumi yang masih memiliki sistem yang sangat sederhana. Bahkan masih cenderung tradisional dan apabila dibenturkan oleh masalah cepat sekali robohnya. Itu di buktikan dengan penurunan jumlah koperasi yang ada di Kota Sukabumi.

Selain faktor di atas, ada juga faktor lain atau variabel lainnya yang diduga kuat mempengaruhi kinerja adalah kultur organisasi, nilai-nilai, sistem dan proses.Faktor-faktor tersebut secara singkat dapat disebut sebagai good corporate governance.Menurut Suprayitno., et al. (2009) IICG (The Indonesian Institute for Corporate Governance), pengertian Good Corporate Governance dapat didefinisikan sebagai struktur, sistem, dan proses yang digunakan oleh organisasi perusahaan sebagai upaya untuk memberikan nilai tambah perusahaan secara berkesinambungan dalam jangka panjang, dengan tetap memperhatikan kepentingan stakeholder lainnya, berlandaskan peraturan perundangan dan norma yang berlaku. Sedangkan menurut Indra Surya (2006:25), good corporate governance terkait dengan pengambilan keputusan yang efektif. Dibangun melalui kultur organisasi, nilai-nilai, sistem. Berbagai proses, kebijakan-kebijakan dan struktur organisasi, yang bertujuan untuk mencapai bisnis yang menguntungkan, efisiensi dan efektif dalam mengelola resiko dan bertanggungjawab dengan memperhatikan kepentingan stakeholder.

Penurunan jumlah anggota Koperasi merupakan indikator yang sangat penting terhadap kinerja Koperasi dari segi transparasi di
Koperasi tersebut, baik dari keuangan maupun informasi untuk para anggotanya. Penurunan jumlah simpanan juga sangat berkaitan sekali dengan akuntabilitas dari kinerja koperasi tersebut. Kurang keprofesionalan dari para pengurus menyebabkan kurangnya rasa percaya dari anggota untuk menyimpan dananya di koperasi. Akibatnya jumlah simpanan di dalam koperasi menurun dan dana yang disalurkan ke anggota pun menurun juga.

Pertanggungjawaban di dalam pengelolaan koperasi terhadap prinsip korporasi yang sehat serta peraturan perundangan yang berlaku. Peraturan yang berlaku di sini termasuk yang berkaitan dengan masalah pajak, hubungan industrial, perlindungan lingkungan hidup, kesehatan/ keselamatan kerja, standar penggajian, dan persaingan yang sehat. Banyak dipandang sebelah mata yang menyebabkan banyak sekali anggota yang loyal keluar dari keanggotaannya. Oleh karena itu dengan adanya fakta penurunan jumlah anggota maka kinerja koperasi di kota Sukabumi perlu melakukan perbaikan.

Banyak sekali koperasi yang tercatat akan tetapi tidak memberikan dampak yang signifikan dari pertumbuhannya. Kemandirian pada tubuh koperasi yang di kuatkan dengan Undang-undang Nomor 25 tahun 1992 dalam nilai dasar koperasi jelas tidak terlaksana sama sekali. Terbukti koperasi yang bermunculan setelah satu tahun berjalan gaungnya sudah tidak ada lagi. Itu menunjukkan kurang baiknya kinerja koperasi.

Adanya kejelasan hak-hak stakeholder berdasarkan sistem hukum dan penegakan peraturan untuk melindungi hak-hak investor khususnya pemegang saham minoritas dari berbagaibentuk kecurangan. Bentuk kecurangan ini bisa berupa insider trading (transaksi yang melibatkan informasi orang dalam), fraud (penipuan), dilusi saham (nilai perusahaan berkurang), korupsi-kolusi-nepotisme (KKN), atau keputusan-keputusan yang dapat merugikan seperti pembelian kembali saham yang telah dikeluarkan, penerbitan saham baru, merger, akuisisi, atau pengambil-alihan perusahaan lain kerap terjadi. Dengan kurangnya informasi yang didapat membuat anggota seakan-akan hanyalah konsumen saja atau nasabah saja tidak lebih dari itu.

Berdasarkan beberapa penelitian tentang tata kelola perusahaan dan hasil observasi awal penerapan tata kelola di perasi, 
maka penting untuk ditemukan suatu bukti empiris tetntang pengaruh prinsip-prinsip tata kelola yang baik terhadap kinerja Koperasi. Kota Sukabumi digunakan sebagai sampel penelitian dengan pertimbangan bahwa perkembangan koperasi di Sukabumi lebih pesat dibandingkan kota lainnya di Jawa Barat. Hasil penelitian diharapkan dapat memberikan kontribusi dalam penerapan tata kelola yang baik pada koperasi di Indonesia.

\section{2.. Telaah Teori dan Pengujian Hipotesis}

\subsection{Teori Keagenan (Agency Theory)}

Pada saat manajer-pemilik adalah pemegang saham tunggal, maka masalah keagenan tidak ada dalam perusahaan (Jensen dan Meckling, 1976).Namun, apabila kepemilikan tersebar yaitu kepemilikan berada di tangan pemegang sahamdan kontrol di tangan manajemen, maka masalah keagenan yang kemungkinan muncul adalah antara pemegang saham dan manajemen. Kepemilikan berada pada pemegang saham dan kontrol berada pada manajemen. Jensen dan Meckling (1976) mengidentifikasi hal tersebut sebagai pemisahan kepemilikan (ownership) dan kontrol (control). Hal ini menimbulkan masalah keagenan antara pemegang saham sebagai prinsipal dan manajemen sebagai agen. Prinsipal adalah pihakyang mendelegasikan tanggung jawab kepada pihak lain (agen) untuk melakukan suatu pekerjaan jasa dan diberi wewenang untuk mengambil keputusan. Agen adalah pihak yang diberi tanggung jawab oleh pihak lain (prinsipal) untuk melakukan pekerjaan yang dapat meningkatkan kesejahteraan prinsipal. Di dalam model agensi, individu (pemegang saham dan manajemen) diasumsikan termotivasi dengan keinginannya sendiri. Gilson dan Gordon (2003) mengemukakan bahwa masalah keagenan dapat dilihat dari dua sisi, yaitu masalah keagenan pertama antara pemegang saham dan manajemen serta masalah keagenan kedua antara pemegang saham pengendali dan pemegang saham non pengendali.Masalah keagenan antara pemegang saham dan manajemen muncul karena adanya pemisahan kepemilikan dan kontrol, sedangkan masalah keagenan antara pemegang saham pengendali dan pemegang saham non pengendali muncul karena adanya insentif dan kemampuan pemegang saham pengendali untuk mendapatkan manfaat privat atas kontrol. Manfaat privat inilah yang mendorong pemegang saham pengendali untuk mempertahankan kontrol perusahaan. Manfaat privat atas kontrol lebih besar apabila kepemilikannya terkonsentrasi.Secara empiris terbukti bahwa konsentrasi kepemilikan terjadi di banyak negara seperti yang ditemukan oleh La Porta et al. (1999), Claessens et al. (2000a), serta Faccio dan Lang (2002). Pemegang saham pengendali memiliki kontrol terhadap perusahaan melebihi hak aliran kasnya. Dengan konsentrasi kepemilikan seperti ini, muncul konflik keagenan antara pemegang saham pengendali dengan pemegang saham non pengendali.

\section{$2.2 \quad$ Kinerja}

Terkait dengan tujuan program dan pencapaian kinerja, Michael West (Srikandi Waluyo,1998:140) memberi penegasan bahwa penentuan tujuan sangat berpengaruh pada kinerja, sehingga perumusan tujuan harus spesifik, dengan perencanaan yang jelas dan terukur, relevan terhadap isu dan berdasarkan pada perkiraan waktu. Menurut Robert S. Kaplan seorang professor pimpinan pengembangan pada Harvard Business School dan David P.Norton seorang pimpinan akademi Renaissance Solutions,Inc. Combining. Balanced scorecard merupakan kerangka manajemen yang menerjemahkan visi dan misi perusahaan ke dalam satu set pengukuran kinerja berdasarkan empat perspektif, yaitu perspektif keuangan, perspektif pelanggan, perspektif prosesbisnis internal, serta perspektif pembelajaran dan pertumbuhan (Kaplan dan Norton, 2001).

Menurut Siagian (2007 : 305) disiplin kerja dirasakan penting, karena jika karyawan tidak berdisiplin dapat mengganggu kinerja karyawan dan stabilitas organisasi. Jika para karyawan banyak yang tidak disiplin dalam bekerja, maka hal itu dapat menyebabkan tidak tercapainya tujuan organisasi. Widyatmini dan Hakim (2008) dalam penelitiannya menyatakan bahwa variabel kompensasi berpengaruh positif secara signifikan terhadap variabel kinerja, yang artinya bahwa semakin tinggi upah yang didapat, semakin tinggi kinerja. Penelitian yang dilakukan oleh Abbas and Yaqoob (2009) menyimpulkan bahwa kompensasi merupakan salah satu faktor yang meningkatkan kinerja karyawan. 


\subsection{Perspektif Keuangan (Financial Perspective)}

Balanced Scorecard menggunakan tolok ukur kinerja keuangan, seperti laba bersih dan ROI (Return on Investment), karena tolok ukur tersebut secara umum digunakan dalam organisasi yang mencari keuntungan atau profit. Tolok ukur keuangan memberikan bahasa umum untuk menganalisis perusahaan. Orang-orang yang menyediakan dana untuk perusahaan, seperti lembaga keuangan dan pemegang saham, sangat mengandalkan tolok ukur kinerja keuangan dalam memutuskan hal yang berhubungan dengan dana. Tolok ukur keuangan yang didesign dengan baik dapat memberikan gambaran yang akurat untuk keberhasilan suatu organisasi. Tolok ukur keuangan adalah penting, akan tetapi tidak cukup untuk mengarahkan kinerja dalam menciptakan nilai (value). Tolok ukur non keuangan juga tidak memadai untuk menyatakan angka paling bawah (Bottom Line). Balanced Scorecard mencari suatu keseimbangan dari tolok ukur kinerja yang multiple-baik keuangan maupun non keuangan untuk mengarahkan kinerja organisasional terhadap keberhasilan. (sienconsultant.ucoz.com).

\subsection{Good Coorperation Governance}

Good cooperative Governance memberikan suatu struktur yang memfasilitasi penentuan visi dan misi dari Koperasi dan merupakan sarana untuk memilih teknik monitoring kinerja. Good cooperative Governance menurut para pakar adalah sebagai berikut:

Menurut Tim KNKG,2006, hal 2, prinsip-prinsip tatakelola perusahaan yang baik ini antaralain (tim KNKG, 2006, hal 5) adalah transparansi, akuntabilitas, responsibilitas, independensi kewajaran dan kesetaraan.

Menurut Suprayitno., et al. (2009) IICG (The Indonesian Institute for Corporate Governance), pengertian Good Corporate Governance dapat didefinisikan sebagai struktur, sistem, dan proses yang digunakan oleh organisasi perusahaan sebagai upaya untuk memberikan nilai tambah perusahaan secara berkesinambungan dalam jangka panjang, dengan tetap memperhatikan kepentingan stakeholder lainnya, berlandaskan peraturan perundangan dan norma yang berlaku. Sedangkan Asian Development Bank menegaskan adanya konsensus umum bahwa Good Governance dilandasi oleh 4 (empat) pilar, yaitu: (1) accountability, (2) transparency, 3) participation, 4) effectiveness and efficiency. Dari berbagai pendapat mengenai prinsipprinsip dan karakteristik Good Governance tersebut diatas, ternyata jumlah komponen prinsip-prinsip Good Governance sangat bervariasi. Namun demikian, prinsip-prinsip tersebut tidaklah berdiri sendiri, tapi saling berkaitan dalam satu kesatuan hubungan yang erat, sehingga masing-masing prinsip menjadi instrumen yang diperlukan untuk mencapai prinsip yang lainnya. Pada Peraturan Menteri Negara Badan Usaha Milik Negara Nomor PER-01/MBU/2011 Tentang Penerapan Tata Kelola Perusahaan Yang Baik Prinsip-prinsip GCG yang dimaksud dalam Peraturan ini, meliputi:

1. Keterbukaan Informasi (Transparency), yaitu keterbukaan dalam melaksanakan proses pengambilan keputusan dan keterbukaan dalam mengungkapkan informasi material dan relevan mengenai perusahaan.

2. Akuntabilitas (accountability), yaitu kejelasan fungsi, pelaksanaan dan pertanggungjawaban Organisasi sehingga pengelolaan perusahaan terlaksana secara efektif.

3. Pertanggungjawaban (responsibility), yaitu kesesuaian di dalam pengelolaan perusahaan terhadap peraturan perundang-undangan dan prinsip-prinsip korporasi yang sehat.

4. Kemandirian (independency), yaitu keadaan di mana perusahaan dikelola secara profesional tanpa benturan kepentingan dan pengaruh/tekanan dari pihak manapun yang tidak sesuai dengan peraturan perundangundangan dan prinsip-prinsip korporasi yang sehat.

5. Kewajaran (fairness), yaitu keadilan dan kesetaraan di dalam memenuhi hak-hak Pemangku Kepentingan (stakeholders) yang timbul berdasarkan perjanjian dan peraturan perundang- undangan.

Berdasarkan teori, kerangka pikir $\mathrm{t}$ pada penelitian ini digambarkan sebagai berikut. 


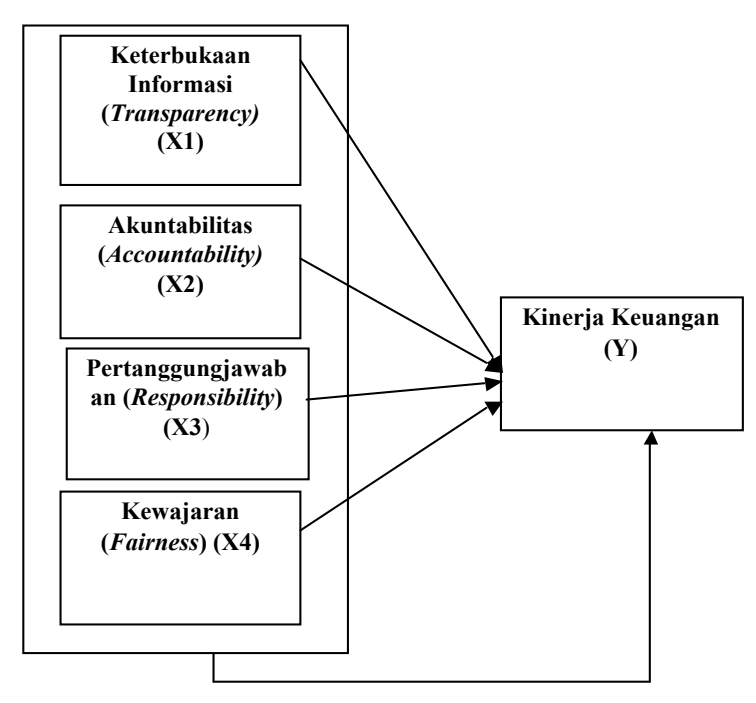

Gambar 1. Kerangka Pikir

Perumusan Hipotesis :

$\mathrm{H}_{\mathrm{a} 1}$ : Terdapat pengaruh yang positif dan signifikan dari keterbukaan informasi, akuntabilitas, pertanggungjawaban, dan kemandirian secara simultan terhadap kinerja Koperasi.

$\mathrm{H}_{\mathrm{a} 2}$ : Terdapat pengaruh yang positif dan signifikan dari keterbukaan informasi terhadap kinerja Koperasi.

$\mathrm{H}_{\mathrm{a} 3}$ : Terdapat pengaruh yang positif dan signifikan dari akuntabilitas terhadap kinerja Koperasi.

$\mathrm{H}_{\mathrm{a} 4}$ : Terdapat pengaruh yang positif dan signifikan dari pertanggungjawaban terhadap kinerja Koperasi.

$\mathrm{H}_{\mathrm{a} 5}$ : Terdapat pengaruh yang positif dan signifikan dari kewajaran secara parsial terhadap kinerja Koperasi.

\section{Metode Penelitian}

Jenis data penelitian ini bersifat kuantitatif dan terdiri atas data primer dan data sekunder :

a. Data Sekunder, jenis data yang diperoleh dari berbagai penerbitan seperti jurnal ilmiah, buku-buku atau litelatur yang berhubungan dengan Koperasi, dan peneliti juga mengambil data dari sumber lain seperti internet, media masa lain.

b. Data Primer, jenis data yang diperoleh dengan cara melakukan survey yang dibantu dengan perangkat kuisioner/ angket.

Dalam penelitian ini diperoleh data primer dengan melalui metode survey yang di bantu dengan menggunakan perangkat kuisioner, populasi yang di jadikan sampel dalam penelitian ini adalah pengurus Koperasi di wilayah kota Sukabumi dengan jumlah Koperasi 373 Koperasi. Teknik sampling dalam penelitian ini menggunakan metode purposive sampling. Menurut kuntjojo (2005) purposive sampling adalah penarikan sampel yang dilakukan memilih subjek berdasarkan criteria spesifik yang ditetapkan peneliti. Sampel menurut arikunto (2005) adalah bagian dari populasi (sebagian atau wakil populasi yang diteliti). Sampel penelitian adalah sebagian dari populasi yang di ambil sebagai sumber data dan dapat mewakili seluruh populasi. Teknik sampling yang digunakan dalam penelitian ini adalah teknik purposive sampling, yaitu penarikan sampel secara purposive merupakan cara penarikan sampel yang dilakukan memilih subjek berdasarkan kriteria spesifik yang ditetapkan peneliti. (Kuntjojo, 2009). Dari jumlah Koperasi di atas maka akan di pilih beberapa Koperasi yang memenuhi kriteria sebagai sampel. Kriteria Koperasi yang akan di jadikan sampel adalah sebagai berikut :

1. Koperasi yang ada diwilayah Kota Sukabumi;

2. Koperasi yang melaporkan RAT ke Dinas Koperasi, Perindustian dan Perdagangan Kota Sukabumi;

3. Koperasi yang melakukan penarikan dana pada anggotanya.

4. Koperasi yang melakukan penarikan dana di luar anggota Koperasi.

Jumlah sampel yang digunakan dalam penelitian ini ditentukan dengan mengacu pendapat Suharsimi Arikunto (2005) Dirumuskan sebagai berikut:

$$
\begin{aligned}
n & =\frac{N}{N \cdot d^{2}+1} \\
& =\frac{373}{373 \cdot(0,1)^{2}+1} \\
& =\frac{373}{4,73} \\
& =79 \text { orang } \\
\text { Dimana : } & \\
\mathrm{n} & =\text { Ukuran sampel } \\
\mathrm{N} & =\text { Ukuran populasi } \\
\mathrm{d} & =\text { galat pendugaan } \\
& \text { Dari kriteria di atas maka jumlah }
\end{aligned}
$$
sampel yang akan di gunakan dalam penelitian ini minimal adalah 79 orang yang akan mengisi kuisioner yang terdiri 
dari Manajer Koperasi, Bagian kepegawean dan Bendahara Koperasi. Didalam struktur organisasi Koperasi minimal pengurus yang ada adalah 3 dan staf yang di bawah pengurus minimal 2 orang, jadi pada tiap Koperasi terdapat 5 responden. Kriteria respondenresponden yang di pilih dalam penelitian ini adalah sebagai berikut : Koperasi di wilayah Kota Sukabumi, Pegawai Koperasi dari level atas hingga bawah, Masing masing Koperasi dipilih minimal 5 responden, Menjawab kuisioner dengan benar dan penuh terisi. Berdasarkan kriteria di atas maka disebar sebanyak 150 kuisioner di Kota Sukabumi. Dan dari 150 kuisioner terkumpul sebanyak 124 kuisioner.

Penelitian ini lebih menitik beratkan pada sumber data primer yaitu sumber data yang dikumpulkan langsung dari obyek penelitian berupa kuisioner yang dibagikan kepada para responden. Kuisioner dipergunakan untuk memperoleh informasi dari responden. Metode Pengumpulan Data Primer adalah data yang diperoleh langsung oleh si peneliti dari obyek penelitian, dalam hal ini peneliti menggunakan kuisioner dalam mengumpulkan data dari para responden. Metode Pengumpulan Data Sekunder merupakan data yang di ambil dari jurnal-jurnal, buku serta UU yang berlaku.

Tempat Penelitian akan dilaksanakan di kota Sukabumi dalam dua tahap meliputi (1) persiapan dan fisibilitas data yang akan dikumpulkan, (2) pengumpulan data sekunder dari pencatatan yang ada serta data primer dari kuisioner dengan responden para manager serta karyawan yang ada di Koperasi di Kota Sukabumi. Pelaksanaan penelitian selama 1 semester di tahun 2014.

Dalam hal ini data dianalisis dengan menggunakan statistik deskriptif. Statistik deskriptif memberikan gambaran atau deskripsi suatu data yang di nilai dari nilai rata-rata (mean), standar deviasi, varian, maksimum, minimum, sum, range, kurtosis, dan keoness (kemencengan distribusi) (Imam Gozali, 2009).

1. Uji Validitas : Uji Validitas digunakan untuk mengukur sah atau valid tidaknya suatu kuisioner. Suatukuisioner dikatakan valid jika pertanyaan pada kuisioner mampu untuk mengungkapakan sesuatu yang akan diukur oleh kuisioner tersebut. (Imam Ghozali :52)

2. Uji Reliabilitas : adalah alat untuk mengukur suatu kuisioner yang merupakan indicator dari Variabel atau konstruk. Suatu kuisioner dikatakan Reliabel atau handal jika jawaban seseorang terhadap pernyataan adalah konsisten atau stabil dari waktu ke waktu.

3. Uji Normalitas : Uji normalitas data dimaksudkan untuk memperlihatkan bahwa data sampel berasal dari populasi yang berdistribusi normal.Didalam model regresi, model regresi yang baik adalah memiliki distribusi normal atau mendekati normal. Untuk meningkatkan hasil uji normalitas data maka peneliti menggunakan one sample kolmogorov smirnov tes, dengan kriteria :

a) Jika asymp. Sig < 0,05 maka model regresi tidak berdistribusi normal

b) Jika asymp. Sig $<0,05$ maka model regresi berdistribusi normal.

4. Uji Multikolonieritas : Digunakan untuk menguji apakah model regresi ditemukan adanya korelasi antar veriabel bebas (independent). Model regresi yang baik seharusnya tidak terjadi korelasi diantara variabel bebas (tidak terjadi multikonieritas). Jika variabel bebas saling berkorelasi, maka variabel-variabel ini tidak ortogonal adalah variabel bebas yang nilai korelasi antar sesama variabel bebas sama dengan nol. Pengambilan keputusan Melihat nilai Tolerance

a) Tidak terjadi Multikolinearitas, jika nilai Tolerance lebih besar 0,10 .

b) Terjadi Multikolinearitas, jika nilai Tolerance lebih kecil atau sama dengan 0,10 .

Melihat nilai VIF (Variance Inflation Factor)

a) Tidak terjadi Multikonieritas, jika nilai VIF lebih kecil 10,00.

Terjadi Multikonieritas, jika nilai VIF lebih besar atau sama dengan 10,00.

5. Uji Heteroskedastisitas : Digunakan untuk menguji apakah ada ketidaksamaan varian dari residual untuk semua pengamatan pada model regresi. Serta untuk mengetahui adanya penyimpangan dari syarat-syarat asumsi klasik pada model regresi, di mana dalam model regresi harus dipenuhi syarat tidak adanya heteroskedastisitas. Jika pada grafik terdapat pada titik yang membentuk suatu pola tertentu dan teratur(bergelombang, melebar, kemudian menyempit), maka telah terjadi heterokedastisitas. Sebaliknya jika tidak ada pola yang jelas serta titik-titik menyebar di atas dan dibawah angka nol pada sumbu Y, maka tidak terjadi heterokedasitas.

6. Uji Hipotesis : Pengujian hipotesis dilakukan 
dengan menggunakan analisi regresi linier berganda yang dilakukan dengan bantuan komputer melalui program spss.

Persamaa regresi linier berganda di rumuskan:

$\mathrm{Y}=\mathrm{a}+\mathrm{b} 1 \mathrm{X} 1+\mathrm{b} 2 \mathrm{X} 2+\mathrm{b} 3 \mathrm{X} 3+\mathrm{b} 4 \mathrm{X} 4+\mathrm{e}$

Dimana :

$\mathrm{Y}=$ Kinerja Koperasi

a $=$ Konstanta

b $=$ Koefisien Regresi

$\mathrm{X}_{1}=$ Keterbukaan Informasi

$\mathrm{X}_{2}=$ Akuntabilitas

$\mathrm{X}_{3}=$ Pertanggungjawaban

$\mathrm{X}_{4}=$ Kewajaran

Hipotesis di uji dengan langkah-langkah sebagai berikut :

7. Uji Simultan (Uji F) : Agar dapat diketahui variabel-variabel bebas berpengaruh secara bersama-sama secara signifikan terhadap variabel terkait dilakukan dengan menggunakan uji $\mathrm{F}$, dengan membandingkan antara nilai $\mathrm{F}$ tabel dengan nilai $\mathrm{F}$ hitung. Apabila hasil dari $\mathrm{F}$ hitung lebih besar dari pada $\mathrm{F}$ tabel, dapat disimpulkan bahwa semua variabel bebas secara bersama-sama mempengaruhi variabel terkait (Y). Dan begitu pula sebaliknya apabila $\mathrm{F}$ hitung lebih kecil daripada $\mathrm{F}$ tabel maka bisa disimpulkan bahwa variabel bebas tidak berpengaruh secara simultan terhadap variabel terkait $(\mathrm{Y})$ Uji Statistik F (mencari F hitung), F hitung dengan rumus :

Fhitung $=\frac{R^{2} / K}{\left(1-R^{2}\right) /(n-k-1)}$

(Priyatno, Dwi : 2010)

$\mathrm{R}^{2}=$ Kefisien determinasi

$\mathrm{n}=$ Jumlah data atau kasus

$\mathrm{K}=$ Jumlah variabel independen

Kesimpulan tolak $\mathrm{H} 0$ atau terima $\mathrm{Ha}$ Jika F hitung $>$ F tabel berarti $\mathrm{H} 0$ ditolak Jika F hitung $\leq \mathrm{F}$ tabel berarti $\mathrm{H} 0$ diterima

8. Uji Parsial (Uji t) : Pengaruh variabel bebas secara parsial terhadap variabel terkait maka Uji t yang digunakan untuk menguji secara parsial masing-masing variabel. Yaitu dengan membandingkan antara nilai t hitung masing-masing variabel bebas dengan $t$ tabel (nilai kritis dengan nilai signifikasi $0,05)$. Jika t hitung variabel bebas, lebih kecil daripada $t$ tabel, atau $t$ hitung lebih besar dari pada $t$ tabel negatif, maka berarti variabel bebas tidak berpengaruh terhadap variabel terkait.Sebaliknya jika $t$ hitung variabel bebas lebih besar daripada t tabel atau thitung lebih kecil daripada $t$ tabel (-), maka berarti variabel bebas berpengaruh terhadap variabel terkait. (tesis karya Anita Mega Lestari)

Rumus t hitung pada analisis regresi (priyatno, duwi : 2010)

$$
\mathrm{T} \text { hitung }=\frac{\mathrm{bi}}{\mathrm{Sbi}}
$$

Dimana :

$\mathrm{Bi}=$ Koefisien regresi variabel $\mathrm{i}$

Sbi $=$ Standar error variabel $\mathrm{i}$

Kriteria pengujian yang di gunakan adalah: Jika t hitung $>$ tabel atau $-\mathrm{t}$ hitung $<-\mathrm{t}$ tabel maka Ho di tolak

Jika $-\mathrm{t}$ tabel $<\mathrm{t}$ hitung $<\mathrm{t}$ tabel maka Ho di terima.

\section{Hasil Penelitian Dan Pembahasan}

\subsection{Hasil Uji Statistik Deskriptif}

Bahwa deskriptif statistic merupakan tahap awal yang digunakan untuk menggambarkan statistic data berupa rata-rata (mean), standar deviasi, varian. Berikut analisi deskriptif dari masing-masing variabel dalam penelitian ini adalah sebagai berikut:

a. Transparansi mempunyai nilai minimum sebesar 5.422 yang terjadi pada koperasikoperasi kota Sukabumi. Nilai maksimum transparansi pada koperasi di kota Sukabumi sebesar 16.738. sementara itu nilai ratarata standar deviasi dari transparasi adalah 11.73869 dan 2.462284 yang menunjukan data tersebut mempunyai sebaran yang luas. Sedangkan nilai variance dari transparansi adalah sebesar 6.063 .

b. Akuntabilitas mempunyai nilai minimum sebesar 7.350 yang terjadi pada koperasikoperasi kota Sukabumi. Nilai maksimum akuntabilitas padakoperasi di kota Sukabumi sebesar 16.796. sementara itu nilai rata-rata standar deviasi dari akuntabilitas adalah 12.08285 dan 2.344843 yang menunjukan data tersebut mempunyai sebaran yang luas. Sedangkan nilai variance dari transparansi adalah sebesar 5.498 .

c. Pertanggungjawaban mempunyai nilai minimum sebesar 7.289 yang terjadi pada koperasi-koperasi kota Sukabumi. Nilai maksimum Pertanggungjawaban pada koperasi di kota Sukabumi sebesar 16.928. 
sementara itu nilai rata-rata standar deviasi dari transparasi adalah 11.94673 dan 2.383182 yang menunjukan data tersebut mempunyai sebaran yang luas. Sedangkan nilai variance dari transparansi adalah sebesar 5.680.

d. Kewajaran mempunyai nilai minimum sebesar 6.132 yang terjadi pada koperasikoperasi kota Sukabumi. Nilai maksimum kewajaran pada koperasi di kota Sukabumi sebesar 16.526 . sementara itu nilai ratarata standar deviasi dari kewajaran adalah 11.37606 dan .207204 yang menunjukan data tersebut mempunyai sebaran yang luas. Sedangkan nilai variance dari kewajaran adalah sebesar 5.324.

e. Kinerja mempunyai nilai minimum sebesar 7.981 yang terjadi pada koperasi-koperasi kota Sukabumi. Nilai maksimum kinerja pada koperasi di kota Sukabumi sebesar 18.582 . sementara itu nilai rata-rata standar deviasi dari kewajaran adalah 13.51379 dan 2.454820 yang menunjukan data tersebut mempunyai sebaran yang luas. Sedangkan nilai variance dari kinerja adalah sebesar 6.027.

\section{Hasil Uji Asumsi Klasik}

Untuk pembahasan dari hasil analisis ini terlebih dahulu melakukan pengujian terhadap pelanggaran asumsi klasik. Pelanggaran terhadap asumsi klasik ini menyebabkan hasil estimasi menjadi tidak akurat, sehingga memerlukan penanggulangan sebelum model tersebut digunakan untuk pengujian hipotesis.

a. Hasil Uji Normalitas

Hasil uji distribusi data normal dilakukan dengan one sample kolmogorov smirnov test menunjukan bahwa besarnya nilai kolgomorov-Smirnov adalah 0,078 dengan Asymp.sig 0,062 Sesuai dengan persyaratan uji distribusi data normal menggunakan one sample kolmogorov smirnov test, karena nilai Asymp. Sig 0,062 maka model regresi dinyatakan terdistribusi normal.

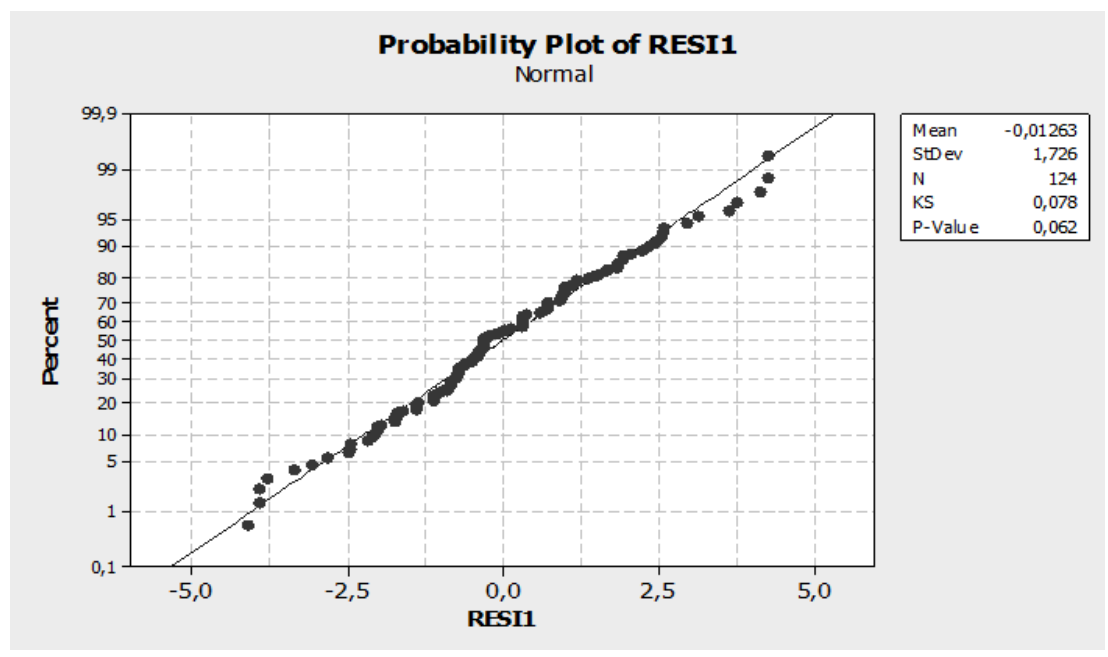

Gambar 2.

Grafik Normalitas

Dari grafik normalitas di atas dapat kita lihat bahwa titik menyebar di sekitar garis diagonal dan mengikuti arah garis diagonal. Nilai probabilitas pengamatan letaknya tidak jauh bahkan sebagian besar ada yang menempel pada garis diagonal sebagai nilai probabilitas harapan yang merupakan potongan antara garis probabilitas harapan dan probabilitas pengamatan, sehingga bisa di artikan distribusi data kinerja adalah normal.

b. Hasil Uji Multikolinieritas

Untuk melihat gejala multikolinearitas antar variabel dalam penelitian ini dapat dilihat dari hasil Collinearitu Statistics. Berikut disajikan nilai tolerance dan VIF pada asing-masig variabel seperti terlihat pada tabel berikut ini : 
Dari pengolahan data maka diperoleh nilai Tolerance untuk variabel transparansi, akuntabilitas, pertanggungjawaban, fairness atau kewajaran yaitu 0,566, 0,469, 0,608, 0,586 dengan demikian tidak ada variable independen yang memiliki nilai tolerance kurang dari 0,10 yang berarti tidak ada korelasi antara variable independen yang nilainya lebih dari 95\%. Sedangkan hasil perhitungan verian inflation factor juga menunjukan hal yang sama, tidak ada satupun veriabel independen yang memiliki nilai VIF lebih dari 10 yaitu $1,8,2,1,1,6$, dan 1,7 jadi dapat disimpulkan bahwa tidak ada multikolinieritas antara variable independen dalam model regresi.

c. Hasil Uji Heteroskedastisitas

Hasil Uji Heterokedastisitas yang dilakukan pengujian oleh peneliti menunjukan hasil sebagai berikut

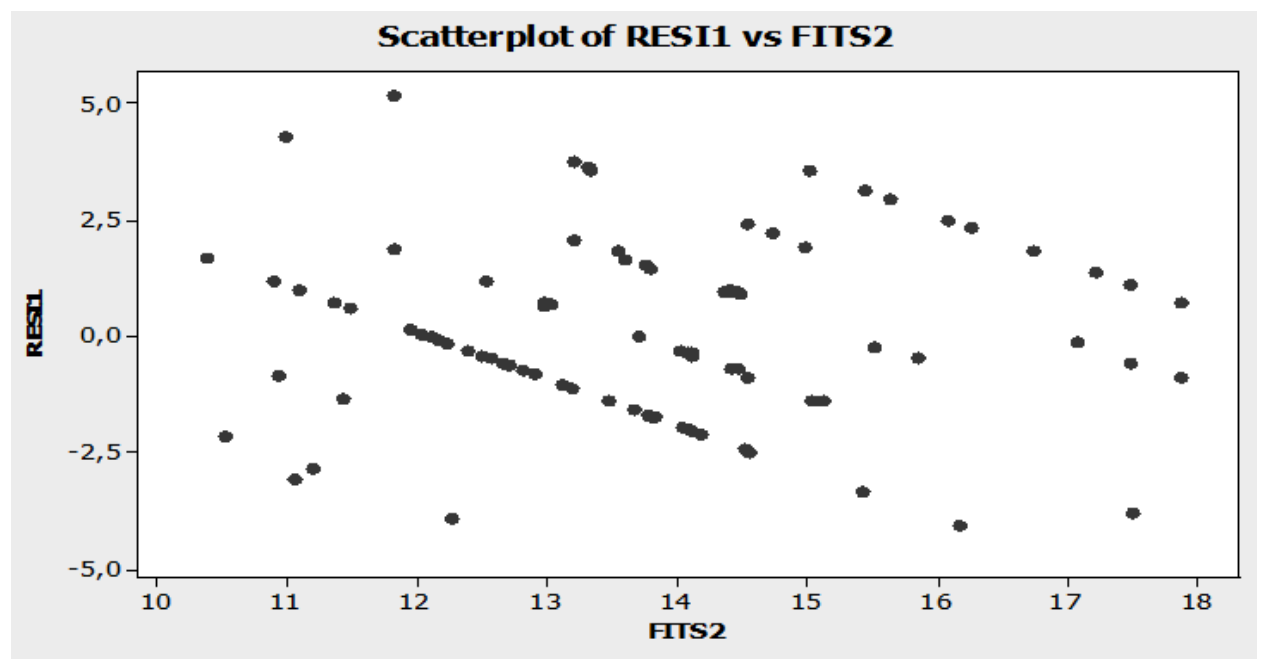

Gambar 3.

Scatter Plot Heteroskedastisitas

Dengan melihat gambar di atas maka dapat kita ketahui bahwa titik-titik menyebar secara acak tersebar baik diatas maupun dibawah angka 0 pada sumbu Y, hal ini dapat disimpulkan bahwa tidak terjadi heteroskedastisitas pada model regresi.

\section{Hasil Pengujian Hipotesis}

a. Hasil Uji F (Simultan)

Dalam hal ini Uji $F$ pada dasarnya menunjukan apakah semua variable independen yang dimasukan dalam model mempunyai pengaruh secara bersama-sama terhadap variabel dependen nya. Hasil menunjukkan nilai p-value 0,000 sehingga secara bersama-sama semua variabel diterapkan akan berpengaruh terhadap model. Dengan hasil analisis regresi diketahui $\mathrm{N}(124), \mathrm{K}(5)$ Dengan $\mathrm{df}=\mathrm{n}-\mathrm{k}-1$ (118) dapat diketahui pula bahwa secara bersama-sama variabel independen memiliki pengaruh signifikan terhadap variabel dependen. Hal ini dibuktikan dari nilai $\mathrm{F}$ hitung sebesar 26,61 dengan nilai signifikan sebesar 0,0000, sedangkan $\mathrm{F}$ tabel 2,29 sehingga $\mathrm{F}$ hitung $>$ F tabel, yaitu 26,61 > 2,33 dan probabilitas jauh lebih kecil dari 0,05 atau 5\% maka model regresi dapat digunakan untuk memprediksi kinerja koperasi, atau dapat dikatakan bahwa transparansi, akuntabilitas, pertanggungjawaban dan kewajaran secara bersama-sama berpengaruh signifikan terhadap kinerja koperasi.

b. Hasil Uji t (Parsial)

Berdasarkan analisa statistik variabel independen transparansi, akuntabilitas, pertanggungjawaban dan kewajaran, berpengaruh signifikan terhadap variabel dependen, yaitu kinerja, dengan tingkat signifikasi 0,005, 0,040, 0,046, dan 0,012 hal ini dikarenakan sig $\mathrm{t}$ variabel transparansi, akuntabilitas, pertanggungjawaban, dan kewajaran lebih kecil dari tinggkat signifikasi sebesar 0,05 dengan $p$-value 0,000

a) Transparansi X1 : Berdasarkan parameter statistic pada variabel uji t di atas terihat bahwa $t$ terhitung variabel transparansi adalah 2,84, dengan menggunakan 
$\alpha=0,05 \%(\mathrm{n}-\mathrm{k}-1)$ diketahui nilai $\mathrm{t}$ tabel $5 \%$ $(124-5-1)=1,657$ sehingga disimpulkan t hitung $>$ tabel atau 2,84>1,657 atau $\mathrm{HO}$ ditolak dan $\mathrm{Ha}$ diterima, artinya transparansi mempunyai pengaruh signifikan terhadap kinerja koperasi.

b) Akuntabilitas X2:Berdasarkan parameter statistic $t$ terhitung variabel akuntabilitas adalah 2,08 dengan menggunakan $\mathrm{a}=$ $0,05 \%(\mathrm{n}-\mathrm{k}-\mathrm{l})$ diketahui nilai t tabel 5\% $(124-5-1)=1,657$, sehingga disimpulkan $\mathrm{t}$ terhitung $>\mathrm{t}$ tabel atau 2,08 $>1,657$ atau HO ditolak dan Ha diterima, artinya akuntabilitas secara parsial mempunyai pengaruh signifikan terhadap kinerja koperasi.

c) Pertanggungjawaban $\mathrm{X} 3$ : Berdasarkan parameter statistic $t$ terhitung variabel pertanggungjawaban adalah 2,02 dengan menggunakan $\mathrm{a}=0,05 \%$ (n-k-1) diketahui nilai $\mathrm{t}$ tabel $5 \%(124-5-1)=1,657$ sehingga dismpulkan $\mathrm{t}$ terhitung $>\mathrm{t}$ tabel atau 2,02 > 1,657 atau $\mathrm{HO}$ ditolak dan $\mathrm{Ha}$ diterima, artinya pertanggungjawaban mempunyai pengaruh signifikan terhadap kinerja koperasi.

d) Kewajaran X4 : Berdasarkan parameter statistic $\mathrm{t}$ terhitung variabel Kewajaran adalah 2,55 dengan menggunakan $\mathrm{a}=0,05 \% \quad(\mathrm{n}-\mathrm{k}-\mathrm{l})$ diketahui nilai $\mathrm{t}$ tabel 5\% (124-5-1) = 1,657 sehingga disimpulkan $\mathrm{t}$ terhitung $>\mathrm{t}$ tabel atau $2,55>1,657$ atau $\mathrm{HO}$ ditolak dan $\mathrm{Ha}$ diterima, artinya kewajaran mempunyai pengaruh signifikan terhadap kinerja koperasi.

\section{Hasil Uji Determinasi}

Uji Adjusted R-Square : Berdasarkan olah data dengan menggunakan SPSS maka dapat diketahui nilai Adjusted $R$ Square (Adjusted R2) sebesar 0,454 ( $45,4 \%)$. Artinya kontribusi pengaruh semua variabel independen (transparansi, akuntabilitas, pertanggungjawaban, fairness) terhadap variabel dependen kinerja adalah sebesar $45,4 \%$. Sedangkan sisanya sebesar $54,6 \%$ dipengaruhi oleh variabel lain yang tidak diteliti. Dikarenakan R square dipengaruhi oleh penambahan jumlah variabel, maka apabila ada penambahan variabel maka R-Square akan meningkat,sedangkan R Adjusted Square tidak terpengaruh oleh penambahan variabel. Oleh karena itu secara otomatis R Adjusted Square lebih kecil dari R Square.

Berdasarkan rumusan masalah dan hipotesis yang dikemukakan dalam bab sebelumnya, untuk menganalisa data dipergunakan analisa regresi berganda diperoleh hasil sebagai berikut:

Model regresi :

$\mathrm{Y}=\alpha+\beta 1 \mathrm{X} 1+\beta 2 \mathrm{X} 2+\beta 3 \mathrm{X} 3+\beta 4 \mathrm{X} 4+\mathrm{e}$

Kinerja $=3,20+0,251$ Transparansi $+0,211$ Akuntabilitas $+0,178$ Pertanggungjawab + 0,236 Kewajaran. Pada persamaan diatas dapat di artikan sebagai berikut :

1. Nilai konstanta $a=3,203$ memberi arti bahwa jika variable bebas diabaikan atau apabila transparansi, akuntabilitas, pertanggungjawaban, dan kewajaran tidak berubah maka kinerja koperasi akan bernilai 3,203

2. Nilai koefisien transparansi sebesar 0,251 angka ini menunjukan bahwa transparansi mempunyai hubungan yang positif dengan kinerja koperasi, ini berarti bahwa apabila akuntabilitas, pertanggungjawaban, dan kewajaran konstan atau tetap maka kinerja koperasi akan mengalami kenaikan sebesar $25,1 \%$

3. Nilai koefisien akuntabilitas sebesar 0,211 angka ini menunjukan bahwa akuntabilitas mempunyai hubungan yang positif dengan kinerja koperasi, ini berarti bahwa apabila transparansi, pertanggungjawaban, dan kewajaran konstan atau tetap maka kinerja koperasi akan mengalami kenaikan sebesar $21,1 \%$

4. Nilai koefisien pertanggungjawaban sebesar 0,178 angka ini menunjukan bahwa pertanggungjawaban mempunyai hubungan yang positif dengan kinerja koperasi, ini berarti bahwa apabila transparansi, akuntabilitas, dan kewajaran konstan atau tetap maka kinerja koperasi akan mengalami kenaikan sebesar 17,8\%

5. Nilai koefisien kewajaran sebesar 0,236 angka ini menunjukan bahwa kewajaran mempunyai hubungan yang positif dengan kinerja koperasi, ini berarti bahwa apabila transparansi, akuntabilitas, dan pertanggungjawaban, konstan atau tetap maka kinerja koperasi akan mengalami kenaikan sebesar 23,6\% 


\subsection{Pembahasan Hasil Penelitian}

Berdasarkan penelitian menyatakan bahwa terdapat pengaruh yang signifikan antara keterbukaan informasi (transparansi) ,akuntabilitas, pertanggung jawaban, dan kewajaran secara simultan terhadap kinerja koperasi. Itu sesuai dengan teori yang di nyatakan oleh Komite Nasional Kebijakan Governance atau KNKG, 2006, hal 2, prinsipprinsip tatakelola perusahaan yang baik ini antara lain (tim KNKG, 2006, hal 5) adalah transparansi, akuntabilitas, responsibilitas, independensi kewajaran dan kesetaraan. Yang apabila kesemuanya berjalan dengan baik maka akan mempengaruhi kinerja kearah yang baik. Hasil penelitian ini sesuai dengan penelitian Komang Meitradi Setyawan1 I Gusti Ayu Made Asri Dwija Putri2 2013 yang meneliti tentang pengaruh good corporate governance terhadap kinerja keuangan Lembaga Perkreditan Desadi kecamatan Mengwi Kabupaten Badung.

Kedua, diperoleh hasilyang menyatakan bahwa terdapat pengaruh yang signifikan antara keterbukaan informasi (transparansi) terhadap kinerja koperasi secara parsial. Keterbukaan informasi sangatlah berpengaruh terhadap kinerja, semakin transparan atau terbuka suatu perusahaan maka kinerja dari karyawan akan semakin baik. Berdasarkan teori yang dinyatakan jurnal ITB Departemen Teknik Planologi transparansi akan tercapai dengan cara membagi atau menyebarkan informasi dan bertindak dengan cara yang terbuka. Hal tersebut berarti memperbolehkan para stakholder untuk memperoleh informasi. Sistem yang transparan memiliki prosedur yang jelas dalam pengambilan keputusan publik dan adanya saluran komunikasi yang terbuka antara berbagai stakeholder dengan aksesibilitas yang baik terhadap sumber informasi. Transparansi dibangun berdasarkan kebebasan untuk memperoleh informasi. Proses kelembagaan, dan informasi tersedia secara langsung terutama bagi pihak-pihak yang berkepentingan. Hasil penelitian ini sesuai dengan penelitian dari Ruth Tria Enjelina Girsang (2013)yang meneliti tentang "Pelaksanaan Prinsip Transparansi sebagai salah satu bentuk prinsip Good Corporate Governance pada PT. Semen Gresik (Persero) Tbk.

Ketiga, diperoleh hasil yang menyatakan bahwa terdapat pengaruh yang signifikan antara akuntabilitas terhadap kinerja koperasi secara parsial. laporan yang akuntabel sangat menunjang keberlangsungan perusahaan. Dengan laporan yang akuntabel maka semakin dipercayanya koperasi tersebut oleh masyarakat, semakin akuntabel loporan juga akan semakin meningkatkan gairah dari karyawan untuk bekerja lebih giat lagi. Dan didalam teori yang dikemukakan oleh world Bank (dalam UNESCAP, 2002) Mendefinisikan akuntabilitas sebagai "The ability to call public official, private employers, or service and use of funds. "Sedangkan menurut UU No 28 tahun 2000 tentang penyelenggaraan pemerintah yang bersih dan bebas dari korupsi, kolusi dan nepotisme, akuntabilitas adalah asas yang menentukan bahwa setiap kegiatan dan hasil akhir dari kegiatan. Penyelenggaraan Negara harus dapat dipertanggungjawabkan kepada masyarakat atau rakyat sebagai pemegang kekuasaan tertinggi Negara sesuai dengan ketentuan peraturan perundang-undangan yang berlaku. Hasil penelitian ini mendukung pendapat dari penelitian CUI-ITB Departemen Teknik Planologi ITB Bandung (2004)yang meneliti tentang "Keterkaitan Akuntabilitas dan Tranparansi dalam Pencapaian Good Governance.

Hasil penelitian keempat menyatakan terdapat pengaruh signifikan pertanggung jawaban terhadap kinerja koperasi secara parsial. Pertanggungjawaban sangatlah penting artinya didalam menjalankan roda perusahaan dalam hal ini koperasi, dengan adanya pertanggungjawaban maka akan bias terukur seberapa sukses perusahaan dalam beroperasi dalam periode waktu tertentu. Menurut Hansen dan Mowen (2005:116) definisi akuntansi pertanggungjawaban adalah sebagai berikut: "Akuntansi pertanggungjawaban adalah sistem yang mengukur berbagai hasil yang dicapai oleh setiap pusat pertanggungjawaban menurut informasi yang dibutuhkan oleh para manajer untuk mengoperasikan pusat pertanggungjawaban mereka." Hasil penelitian tersebut juga di dukung oleh penelitian yang dilakukan Ardiani dan Wirasedana (2013) tentang pengaruh penerapan akuntansi pertanggungjawaban terhadap efktivitas dan pengendalian biaya. Berikutnya, hasil penelitian diperoleh hasil terdapat pengaruh yang signifikan kewajaran terhadap kinerja koperasi secara parsial dalam hal ini tingkat kewajaran atau keadilan di tubuh koperasi memang sangatlah penting peranannya. Dengan semakin 
adil suatu koperasi terhadap anggota ataupun penguru maka tingkat loyalitas nyapun akan semakin tinggi dan itu berpengaruh terhadap kinerja karyawan yang semakin meningkat pula. Dengan terjadi peningkatan kinerja karyawan maka pertumbuhan koperasipun akan semakin meningkat. Di dalam peraturan Menteri Negara Badan Usaha Milik Negara Nomor: per 01/ MBU/2011 tentang tata kelola perusahaan yang baik: Kewajaran (Fairness), yaitu keadilan dan kesetaraan di dalam memenuhi hak-hak Pemangku Kepentingan (Stakeholders) yang timbul berdasarkan perjanjian dan peraturan perundang-undangan. dalam UU No25 tahun 1992 bagian kedua prinsip koperasi Pasal 5 menyatakan bahwa pembagian sisa hasil usaha dilakukan secara adil sebanding dengan besarnya jasa usaha masing-masing anggota. Hasil penelitian ini sesuai dengan penelitian yang dilakukan oleh Sutarti, Enjang Tachyan B. dan Adilah Saesar pada tahun 2012 yang meneliti tentang "Evaluasi atas Penerapan Pernyataan Standar Akuntansi Keuangan 101 dalam Kaitannya dengan Kewajaran Penyajian Laporan Keuangan pada PT. Bank Jabar Banten Syariah.

\section{Simpulan, Keterbatasan Dan Implikasi Hasil Penelitian}

Berdasarkan hasil penelitian yang telah dilakukan oleh peneliti, maka penelitian menyimpulkan bahwa transparansi, akuntabilitas, pertanggungjawaban dan kewajaran berpengaruh signifikan terhadap kinerja koperasi secara simultan. Terdapat pengaruh signifikan antara trasparansi (keterbukaan informasi) terhadap kinerja secara parsial. Terdapat pengaruh yang signifikan antara akuntabilitas terhadap kinerja koperasi secara parsial. Terdapat pengaruh signifikan antara pertanggungjawaban terhadap kinerja koperasi secara parsial. terdapat pengaruh signifikan antara kewajaran terhadap kinerja koperasi secara parsial.

Penelitian ini memiliki keterbatasan dalam menggunakan metode kuisioner sehingga kesimpulan yang dikemukakan berdasarkan pada data yang terkumpul melalui penggunaan instrument tertulis. Jumlah responden penelitian yang memang cukup kecil yaitu sebesar (124 responden), sehingga data yang diperoleh belum menggambarkan kondisi secara luas, karena dengan menggunakan jumlah responden yang lebih besar akan menggabarkan kondisi secara nyata. Pada peneliti-peneliti berikutnya perlu diperhatikan beberapa hal antara lain :

1. Penelitian tidak hanya pada kota Sukabumi saja tetapi meliputi kabupaten sukabumi yang memang wilayahnya cukup luas.

2. Responden dalam penelitian sebaiknya diperbanyak agar kualitas dari penelitian semakin akurat.

3. Melakukan wawancara langsung dengan responden menambah semakin akuratnya data, serta laporan RAT dari koperasi bisa sebagai acuan juga dalam penelitian.

Kepada pengurus koperasi diharapkan akan lebih memperhatikan keadilan dan keterbukaan di segala hal agar anggota akan merasa percaya kepada pengurus koperasi. Kepada anggota koperasi bahwa transparansi akuntabilitas pertanggungjawaban dan kewajaran (keadilan) akan sangat berpengaruh terhadap kinerja koperasi, dan bisa dijadikan acuan untuk kemajuan koperasi mendatang. Kepada pemerintah agar lebih memperhatikan tentang pertumbuhan dari koperasi di wilayah kota Sukabumi pada khususnya yang berkaitan dengan transparansi, akuntabilitas, pertanggungjawaban dan kewajaran (keadilan) dengan meminta laporan RAT pada tiap taun nya. Bagi akademisi penelitian ini bisa dijadikan acuan untuk melakukan penelitian yang lebih mendalam dan lebih sempurna lagi

\section{Daftar Pustaka}

Ardiani, Ni Made Suari dan Wirasedana, I Wayan Pradnyantha, 2013. "Pengaruh Penerapan Akuntansi Pertanggungjawaban terhadap Efektivitas Pengendalian Biaya." $E$ Jurnal Akuntansi Universitas Udayana 5.3 (2013):561-573.

Arikunto, Suharsimi,2005, Manajemen Penelitian, PT Rineka Cipta, Jakarta.

Brigham \& Houston, 2001. Manajemen Keuangan. Yogyakarta: Eralangga.

CUI-ITB, Departemen Teknik Planologi ITB, 2004.“Keterkaitan Akuntabilitas dan Transparansi dalam Pencapaian Good Governance."Jurnal Perencanaan Wilayah dan Kota Vol. 15 No. 1 2004, hlm.34-47.

Girsang, Ruth Tria Enjelina, 2013. Pelaksanaan Prinsip Transparansi sebagai salah satu Bentuk Prinsip Good Corporate Governance pada PT. Semen Gresik (Persero) Tbk. Malang: Universitas Brawijaya. 
Ghozali, Imam 2013, Aplikasi Analisis Multivariate Dengan Program SPSS21, Badan Penerbit Universitas Diponegoro, Semarang.

Handoko, T Hani, 2003. Manajemen. Yogyakarta: BPFE.

Kaplan, R.S., and Norton D.V.,1996. Translating Strategy into Action: Balanced Scorecard. Boston: Harvard College.

Kaplan, R.S., and Norton D.V., 2000. Having Trouble with Your Strategy? ThenMap It, Harvard Business Review on Measuring Corporate Performance, 7, Boston: Harvard Business School Press.

Kaplan, R.S., and Norton D.V., 2004. Strategy Maps: Converting Intangible Assets into Tangible Outcomes. Boston: Harvard Business Scholl Press.

Komite Nasional Kebijakan Governance (KNKG),2006 Pedoman umum good Corporate Governance Indonesia, Jakarta

Kuntjojo. 2009. Metodologi Penelitian. Universitas Nusantara PGRI Kediri. Kediri.

Mulyadi, 2001. Akuntansi Manajemen. Yogyakarta: Salemba Empat.

Mulyadi, 2001. Balanced Scorecard: Alat Manajemen Kontemporer untuk Pelipatganda Kinerja Keuangan Perusahaan. Jakarta: Salemba Empat.

Perda No. 3 Tahun 2002. Transparansi Penyelenggaraan Pemerintahan Kota Gorontalo, Pemkot Gorontalo.

Priyatno,Duwi,2010 ,Paham Analisa Statistik Data Dengan SPSS, Mediakom, Yogyakarta.

Pos Kota, 2012, www.m.poskotanews. com/2012/03/29

Ridwan, 2006, Metode dan Teknik Menyusun Tesis, Alfabeta, Bandung.

Setyawan, Komang Meitradi dan Putri, I GustiAyu made Asri Dwija, 2013. "Pengaruh Good Corporate Governance terhadap Kinerja Keuangan Lembaga Perkreditan Desa di Kecamatan Mengwi Kabupaten Badung."'E-Jurnal Akuntansi Universitas Udayana 5.3 (2013):586-598.

Siagian, Sondang P. 1996. Filsafat Administrasi. Jakarta:PT.Gunung Agung.

Siagian, Sondang P.1997. Organisasi, Kepemimpinan \& Perilaku Administrasi. Jakarta : PT.Gunung Agung.

Sutarti, Enjang Tachyan, dan Adilah Saesar, 2012. "Evaluasi Atas Penerapan Pernyataan Standar Akuntansi Keuangan 101 dalam Kaitannya dengan Kewajaran
Penyajian Laporan Keuangan pada PT. Bank Jabar banten Syariah."Jurnal Ilmiah Ranggagading, Volume $12 \mathrm{~N} .2$ Oktober 2012:102-109.

Undang-Undang Koperasi Nomor 25Tahun 2012.

UNDP, 1994, Governance for Sustainable Human Development. UNDP Policy Document online. http://www.magnet.undp. org/policy/chapter1.htm $\{6$ september2003\}. www.kota sukabumi dalam angka 2012.com www.sienconsultant.ucoz.com 